\title{
Adaptive Expertise-In Understanding and Teaching "Eco-Friendly" Design, Are Teachers Googling It Right?
}

\author{
David Ellis', Bill Boyd ${ }^{2}$ \\ ${ }^{1}$ School of Education, Southern Cross University, Coffs Harbour, Australia \\ ${ }^{2}$ School of Environment, Science and Engineering, Southern Cross University, Lismore, Australia \\ Email: david.ellis@scu.edu.au
}

Received 10 June 2015; accepted 27 December 2015; published 30 December 2015

Copyright (C) 2015 by authors and Scientific Research Publishing Inc.

This work is licensed under the Creative Commons Attribution International License (CC BY).

http://creativecommons.org/licenses/by/4.0/

(c) (i) Open Access

\section{Abstract}

Any curriculum is a construct of perceived social, political and economic needs developed at a point in time. Given that these needs are in a constant state of flux, the curriculum is subjected to periodical renewal and development processes. Gaining more visibility in the iterations of curriculum documentation is the need for Australians to be more aware of their activities impacting on the environment. Comparable to a specific curriculum document, the content knowledge delivered through initial teacher education is specific to the conditions at a point in time, requiring teachers to adapt as the curriculum evolves. Peering through the lens of teacher content knowledge, research has shown that teachers need to efficiently adapt to these changes and effectively develop their expertise in the new content material. Those that can innovate in applying their existing knowledge to the new content are said to possess adaptive expertise. Given the breadth and diversity of school curriculum, the economisation of formalised professional learning opportunities does not address the shortfall in teacher content knowledge. As a result, qualified teachers have resorted to autonomous methods of professional learning to bridge the knowledge gap. This study examines whether autonomous professional learning approaches are an effective method for teachers to gain an understanding of new syllabus content. Using a case study of technology education teachers self-educating around the concepts of eco-friendly technology education, the study identifies the intrinsic motivation of teachers to know and understand their evolving subject, and provides a basis for self-directed and autonomous professional learning. What this results in is the successful development of a basic understanding of new information and concepts in technology education.

\section{Keywords}

Adaptive Expertise, Curriculum, Eco-Design, Graphics, Sustainability, Teacher Professional Learning 


\section{Introduction}

School curriculum is a dynamic concept as, regardless of the set curricula (or course), every classroom is different. What can account for the difference? Grundy (1998) believes that curriculum is a result of what happens when teachers and students are engaged in the curriculum. It is seen as the action between the four elements of teachers, students, the environment and the subject matter (Grundy, 1998; Schwab, 1969). In the context of linking this paper to the work of Grundy, the curriculum and the activities associated with it are very much influenced by the expertise of the teacher and their understanding of the subject matter that they are employed to teach. There has been a global trend for standardised curriculum documents, and "teachers no longer have the discretion to plan their own curriculum to the extent that they once could" (Gough, 2002: p. 1208). As teachers base their lesson content from the curriculum documents that they are employed to teach, teacher expertise comes into question when curriculum is reviewed, redeveloped and ultimately changed.

The question that arises from this situation is: Following a teacher's initial teacher education (training), where they graduate into the profession with knowledge about a particular domain or curriculum specialisation, be it English, Biology, or History, if there is a significant change in syllabus documents, how do teachers adapt and gain the new knowledge and expertise that is required to teach the new subject matter?

\section{Education Context}

\subsection{Why Do Curriculum Documents Change?}

Australia, like any nation, desires a world-class curriculum (ACARA, 2012: p. 5). One may argue that the term world-class, indicates that there are standards to be met to enable our future citizens to "complete in the global economy on knowledge and innovation" (MCEETYA, 2008: p. 4; NAAEE, 2010). The last twenty years have witnessed the development of educational goals in Australia, and as the ink has dried on these drafts, the world has continued to change. As a result of examples such as technological change, globalisation and climate change, curriculum cannot become irrelevant to contemporary issues, and must be designed to prepare "all young Australians, to become competent and contributing members of the community" (ACARA, 2012: p. 10). Curriculum development is, therefore, a highly political process, in which elected representatives consider the major economic, social and environmental stakeholders in the development of goals that will enable future citizens to "meet the changing expectations of society" (ACARA, 2012: p. 7). This article seeks to use the implementation of the interchangeable terms of environmentally-friendly and ecologically-friendly (or eco-friendly), and the broader related concepts of environmental education and sustainability into curriculum documents, to provide an example of how curriculum changes and how teachers, who may have been experts in a domain, need to quickly adapt and acquire new knowledge and understandings to be experts once again.

Curriculum is being influenced by the contemporary push for improved for environmental understanding and engagement, be it labelled as environmental education, sustainability, or education for sustainable development (ESD). These terms have arisen from the growing global push to reduce the human impact on our planet with a current (and increasing) population of over 7 billion people (UNDESA, 2011). Any mitigation of human impact could be coined as being more "environmentally" or "ecologically (eco) friendly". In an effort to develop human existence without compromising the diversity and health of the environment, the term sustainable development was first coined by Gro Brundtland in her address to the World Commission on Environment and Development; the report titled, Our Common Future, also known as The Brundtland Report, was presented in 1987 when the world population was only 5 billion (Geohive, 2014). The report defined sustainable development as development that "meets the needs of the present without compromising the ability of future generations to meet their own needs" (Our Common Future, 1987). In reaction to the Brundtland report, 178 governments (including Australia) adopted the Agenda 21 action plan at the Rio Summit in 1992 as the impetus to initiate strategies that will mitigate human impact on the environment (UNCED, 1993; Division for Sustainable Development, 2009).

To learn how to live more sustainably, Gough (2002) states that environmental education was proposed to sit across academic disciplines to enable students to gain a greater understanding through a holistic approach. However, the danger here is that teachers across the range of disciplines may not be knowledgeable themselves, or the discipline area was not used to addressing social issues (Robottom, 1983). It is the unpreparedness of these disciplines, in particular the teachers, that are the major concerns for a satisfactory understanding of environmental issues and sustainability. 
Even though environmental education can be found in the science curricula in the 1970s (Gough, 2002), it has remained relatively invisible in other disciplines (Tilbury, 1995). It was not until the 1989 Hobart Declaration, where political will influenced the inclusion of environmental education for schools to develop, that "an understanding of, and concern for, balanced development and the global environment" and "a capacity to exercise judgement in matters of morality, ethics and social justice” became acknowledged (MCEETYA, 1998: p. 11). At the time, school curricula in Australia were diverse, with the eight States and Territories being responsible for the development of curriculum document into syllabi. The Hobart Declaration in 1989, however, was the beginning for the development of an Australian Curriculum. Since then, the education goals developed in Hobart have been superseded from subsequent until their present day form re-drafted in Melbourne (2009).

Tuncer et al. (2009) and Darling-Hammond et al. (2005) believe that, in order to improve the environmental literacy of all students, education sectors mustequip the teachers with the knowledge themselves, and that teachers need to become life-long learners. This may prove to be challenging as pre-service teachers train over a relatively short period of time when "not everything can be taught" (Darling-Hammond et al., 2005), and may graduate without receiving adequate environmental education, or information on environmental education pedagogy. As an impediment to the development of environmental knowledge in the future teacher workforce, Christie et al. (2013) suggest that few universities "are actively incorporating sustainability in the classes of all studies” (p. 392), despiteinitiatives such as the Talloires Declaration, since 1990, encouraging universities to incorporate sustainability into Higher Education. Unfortunately, most of the action has focused on campus operational matters "rather than on pedagogic or curricular reform" (Christie et al., 2013: p. 386).

As political will and the various knowledge industries instil environmental education into the curriculum, therefore, the lack of trained teachers in this area indicates the burgeoning gap in teacher knowledge. Even though it has been documented that sustainability would be better served holistically (Tilbury, 1995), and that the Talloires Declaration had been in place since 1990, the majority of Australian academics from non-science (therefore multidisciplinary) disciplines do not teach education for sustainability in their classes (Christie et al., 2013). Unfortunately, as education systems are not quick to react to change, any exposure in pre-service teacher environmental knowledge has been the result of an autonomous effort by "a few interested and enthusiastic academics" (Christie et al., 2013: p. 393).

Zak \& Munson (2008) consider the importance of adequate teacher training in environmental education, if there is to be progress towards improving student learning outcomes, particularly in producing environmentally literate citizens. Their research determined the need for teachers to understand ecological concepts before they can effectively teach their own students. The literature used concept mapping as a way of gauging the participants understanding of ecological concepts, and concluded that the participants had a general understanding of ecological concepts. However, the researchers noted that a solid understanding was needed in pre-service teachers before they begin teaching the next generation of environmentally literate citizens. Naturally, as teachers identify gaps in their own knowledge, they should then seek out professional learning opportunities to bridge the knowledge gap. Barron et al. (2005) tested whether there is a "gap" between professionals (key informants) interpretation and school teachers' interpretation of what is ecologically friendly, and concurred with Zak \& Munson's concerns regarding the impediment to environmental educational outcomes. They state that "sustainability issues have found their way into the curriculum over a number of years" (p. 42), and discussed concerns regarding what they called academics' "naïve understanding” (p. 43) of environmental education.

Motivated countries are developing initiatives to increase awareness and a culture of environmental consideration: "governments around the world have been invited, under the banner of the UN Decade of Education for Sustainable Development (UNESCO, 2007; Mulà \& Tilbury, 2011), to strengthen their contribution to sustainable development through a focus on education” (Cornish, 2005: p. 3). Australia is one of these countries, although we can learn from these lighthouse countries. In Scotland, progress made in the early years of education is being hampered in the secondary school setting. Fraser (2010: p. 67) stated that, "Secondary schools are tasked with becoming sustainable institutions". Scottish schools participate in an international award program called "Eco-Schools". Success in achieving sustainability objectives has been enjoyed in nursery and primary schools in Scotland, whilst the secondary schools have been finding this challenging. Fraser pointed out three reasons for secondary schools to lag behind the others: a shortage of time, a lack of awareness of the eco-projects available, and teacher/management expertise. The importance of these findings for this article, is the focus on developing the teacher in improving educational outcomes. Embedded within many of the current Australian Curriculum and NSW syllabus documents are sustainability outcomes, and as a result, like Scotland, 
Australian schools have become institutions pushing the concepts of “sustainability”. To deliver this content we now need to look towards the development and learning processes to enable teachers to satisfy these outcomes.

\subsection{Teacher Professional Learning for Adaptive Expertise}

The dilemma for teachers is that pre-service teacher educators are trained over a relatively short period of time. As a consequence of time constraints, Darling-Hammond et al. (2005) recognise the reality that "not everything can be taught” (p. 359) in the crowded curriculum of an initial teacher education (ITE) program. Given the inadequacy of teacher education programs (Palardy \& Rumberger, 2008; Bayer, 2014; Hirsh, 2001) to prepare pre-service teachers for the diverse role that teaching encompasses, university programs should prepare students to accept change and adopt the position that teacher education programs should "lay a foundation for lifelong learning” (Darling-Hammond et al., 2005: p. 359). Relevant to both novice and experienced teachers, professional learning (ordevelopment) is to be considered an extension to pre-service teacher education (Starkey, 2009), and in the context of a changing world, changing curriculum this approach and mindset of adaption and further development is necessary in teachers, "giving up old routines and transforming prior beliefs and practices” (Darling-Hammond et al., 2005: p. 365).

In an effort to provide standards and structure to teacher development, and to improve the overall professionalism and quality of the teaching workforce, the Australian Institute for Teaching and School Leadership (AITSL) was established in 2010. In the creation of benchmarks of excellence in teaching practice, AITSL developed a set of seven national teacher standards-called the National Professional Standards for Teachers (NPST) to develop the capacity of the teaching workforce. Upon entering the workforce, teacher graduates in each State and Territory are provisionally registered as teachers until they can provide evidence of their ability to meet these standards. Once they have demonstrated that they are operating at proficient level, they can be fully registered as a "Proficient" teacher (AITSL, 2011). The significance of the NPSTs is that they explicitly require teachers from the proficient career stage to plan, undertake and engage in professional learning (AITSL, 2011: pp. 11-12). This requirement has been supported by the Education Minister of New South Wales (NSW), who has stated that, “of all professions, it is essential for teachers to continue learning” (DEC, 2014), as well as creating the policy that requires teachers to continue engaging in professional development if they wish to remain an accredited teacher.

The broad term of teacher professional learning or development-sometimes coined as in-servicing trainingthat is given to employees during the course of employment (Collins, 2014) can encompass both passive and active engagement, and can be undertaken in either traditional or non-traditional modes (Bayer, 2014). Professional learning is defined as "the formal or informal learning experiences undertaken by teachers and school leaders that improve their individual professional practice, and a school's collective effectiveness, as measured by improved student learning, engagement with learning and wellbeing” (AITSL, 2013: p. 5). Examples of traditional or formal professional learning opportunities include attendance at conferences, and listening to a guest speaker with an expertise in a particular area. More engaging structured courses, such as workshops, enable teacher participation or even assessment. Less formal or non-traditional opportunities may consist of opportunities such as professional reading, mentoring, or personalised and self-directed learning activities (Bayer, 2014: p. 321).

In an attempt to analyse why some countries have been performing well in the global Organisation for Economic Cooperation and Development (OECD) Programme for International Student Assessment (PISA) tests, Hargreaves \& Shirley (2012) have case studied the educational settings of high-ranking countries. Of significance is the case study on Alberta (Canada), the highest ranked English-speaking region. In recent decades, countries like Australia, the United States and England have been developing top-down policy around standardisation of curriculum, and the development of endorsed teacher professional learning. In contrast, a bottom-up approach fostered by the province of Alberta, has accepted the risk as it trusts the professionalism of teachers to innovate and determine their own professional development needs and learning communities. Educators are empowered to "initiate their own projects” and follow “individual passions” (Hargreaves, \& Shirley, 2012: p. 100), as they become intrinsically motivated to engage as "developers, initiators of and inquirers into change instead of just being trained to deliver government strategies” (Hargreaves, \& Shirley, 2012: p. 100).

This approach could be considered both realistic and pragmatic as often time, unsuitability (Ball \& Cohen, 1999) or the lack of opportunity may impede teachers' access to structured professional development (OECD, 2009: p. 67; DEC, 2013: p. 15), causing teachers to seek more informal, unstructured opportunities. This may 
contradict the current Australian approach, which seeks to encourage teachers to engage in endorsed professional learning opportunities through the gathering of evidence of teachers meeting and demonstrating their mastery of the NPSTs. However, if the approach of self-directed professional learning and the development of professional learning communities are resulting to positive educational outcomes in Alberta, then this approach is may be considered to be valid, and worthy of consideration in Australia.

In a teaching context, expertise in any domain-specific curriculum specialisation is not only based of on initial teacher training, but also upon "the accumulation of experience" (Hatano \& Inagaki, 1986). With expertise comes a teacher's ability to anticipate behaviours, questions, and change pedagogy to suit the learners (Darling-Hammond et al., 2005; Ball \& Cohen, 1999). Working in a busy school environment, dealing with a number of students and teaching across multiple subjects, is a complex and challenging role which requires teachers to be flexible, innovative and use their time efficiently. A changing curriculum results in additional work, re-developing programs, lessons and teaching resources and revising assessments to name a few. Looking through the curriculum lens, to retain expertise (mastery) of a particular subject is essential to enable result in the best possible educational outcomes for students. In order to retain this in a changing curricula, teachers are required to possess the adaptive expertise (Hatano \& Inagaki, 1986), to quickly regain mastery of the new subject content, to continue in providing a quality learning environments, and to cater for the diverse needs of students as circumstances may be unpredictable (Lin et al., 2005).

\subsection{Characteristics of Adaptive Expertise}

According to the work of Hatano \& Inagaki (1986), what distinguishes adaptive experts from those categorised as routine experts, is the ability to be flexible and innovative to solve problems and develop their knowledge further (De Arment et al., 2013; Bohle Carbonell et al., 2014). It is the balance between the knowledge and skills to work efficiently, and the ability to apply this knowledge in different contexts to innovate and build on their existing knowledge (Schwartz et al., in press). Identified and modified from a review of literature into adaptive expertise by De Arment et al., 2013, the following lists the common characteristics of adaptive experts.

1) The ability to use their expertise in knowledge and skills to perform a task efficiently. This is similar to routine experts (Hatano \& Iganaki, 1986; Kimball \& Holyoak, 2000; De Arment et al., 2013).

2) Their ability to demonstrate flexibility in their application of knowledge to problem solve unfamiliar situations (Hatano \& Iganaki, 1986; Bransford et al., 2005).

3) The ability to balance both efficiency and innovation (Schwartz et al., in press; Mylopoulos \& Regehr, 2009).

4) Willingness to take calculated risks to innovate, building new knowledge (Bransford 2004; Crawford \& Brophy, 2006).

5) A curiosity and innate desire to continuously build on their knowledge and skills recognising if and when their current levels of understanding are inadequate (Bransford et al., 2000; Crawford \& Brophy, 2006; Kennedy, 1999; Swartz et al., 2005).

6) Critical metacognitive skills to account for multiple perspectives (Lin et al., 2005; Bransford et al., 2005).

Aside from the issues surrounding classroom managements, the challenge for teachers from a curriculum re-development perspective to is know what information needs to be retained, modified or let go. Fortunately, with the current trend of the documentation of explicit educational outcomes (Gough, 2002), the new information that needs to be learnt is explicitly documented in curriculum and syllabus documents. Given the need for teachers to complete diverse activities on a daily basis, and that subject areas (or learning areas, the term used in Australian curricula) within the secondary school curriculum are often diverse, teachers need the versatility borne of the skills of adaptive expertise to remain knowledgeable across the knowledge areas they are teaching. An example of this required versatility is a junior secondary science high school teacher who is required to teach science across a range of disciplines such as biology, chemistry, and physics, even though their teacher training, a graduate diploma in teaching, may have followed a biology-related science degree.

Using the learning area or discipline of technology education as an example, the syllabus content of the NSW of the Graphics Technology course requires teachers to have a diverse range of skills and knowledge in range of areas from Architectural Design to Computer Animation (NSW Board of Studies, 2003). Given the time constraints in a teacher education degree where, for example, pedagogy, psychology, literacy and numeracy are also studied along with areas of curriculum specialisation, the opportunity for teachers to develop expertise in all of these areas is quite limited. The result of this situation supports the statement by Darling-Hammond et al. (2005) that "not everything can be taught" (p. 359), and validates the notation that teachers need to engage in profes- 
sional learning in order to fully understand the curriculum they are employed to deliver.

\section{Methodology}

This article adopts a case study methodology to provide insight into the implication for teachers as they seek to gain mastery of changes to content and approach in a subject that they are required to teach. Case study methodology is an integrated approach of enquiry that uses unique examples of social situations as the basis of deep description and analysis, to gain insight into questions of how and why a social process or phenomenon works. It is, according to Yin (2009: p. 2), the "preferred method where 1) "how" and "why" questions are being posed, 2) the investigator has little control over events, and 3) the focus is on contemporary phenomenon within real-life context”. It is typically used where there are more variables than data points, and insight into complex social processes are sought rather than simply describing pattern or seeking a simple cause-and-effect relationship. For the purposes of gathering data for this case study, the methods of collecting the information will be gathered in three different ways.

Firstly, to determine the motivation behind why teachers may need to develop an understanding of eco-design, it was important to know how the word "ecologically" was embedded into the Graphics Technology Syllabus (NSW Board of Studies, 2003). The first author has taught in Technology Teacher Education programs, and so is familiar with the syllabus review and development processes; he also understands that knowledge regarding ecology is not a component of Technology Education teacher training. Analysis of past and present syllabus documents will reveal when and why knowledge of ecology appeared in the syllabus. This analysis will be placed in the context of relevant Australian federal government policies to determine what external influences may have impacted on the syllabus content to make eco-design a relevant educational outcome to Graphics Technology.

Secondly, current or recent Graphics Technology teachers will be surveyed to determine how they understand ecologically friendly architectural spaces, and how they had acquired this knowledge and understanding. This survey is predicated on the understanding that Education for Sustainable Development is a relatively new consideration in the curriculum, and that teachers who have taught the Architectural Drawing Option Module may not have had any formal training in this area. Teachers in New South Wales teachers who have taught the Architectural Drawing Module of the Graphics Technology syllabus to Year 10 students were surveyed using a standard online survey tool, Qualtrics.

Thirdly, to determine the accuracy of teacher's understanding of eco-design, this study interviewed professional people — an Architect, a representative from Coffs Harbour City Council's Town Planning Department, and an Ecological consultant - who work in areas related to the nexus between human settlements and the local environment. Data collection was via face-to-face semi-structured interviews, recorded on audio tape and transcribed.

\subsection{Selection of the Teacher Participants}

Teachers who are currently, or have recently (recently can be considered as the last few years- this isn't crucial to the study because the current syllabus document has been in place since 2003) delivered the Architectural Drawing Option Module of the Graphics Technology subject will be asked if they wish to volunteer to participate in the survey. As Architectural Drawing is an "Option” Module, this means that not all students studying Graphics Technology will be taught this. Option Modules are only delivered to Year 10 students following the completion of "Core" Modules in Year 9. As a result, it is not known exactly how many students are taught this Module in NSW, as teachers are not required to disclose this information to the NSW Board of Studies (meaning that there is no data available on student numbers).

Considering that schools are not required to disclose information on modules offered, an effective way to recruit participants is to ask for volunteers on a public online forum of Technology Education teachers who may teach this subject. The online forum (called ESNET-Engineering Studies Network), is open to both males and females consisting of over 1300 teachers from State, Catholic and Independent education systems in NSW (although there are members from the states of Queensland and Victoria as well). ESNET is a popular online forum that provides topical dialogue, information and resource sharing for all subjects across the Technology Education discipline.

Within the online ESNET forum, teachers who wish to participate in the survey can volunteer to access the survey via the online Qualtrics survey link. No other identifiable contact information is required from the teacher unless they wish to obtain information on the results of the study. 
The anticipated number of Teacher Participants in this online survey study is indeterminable, but a number greater than 10 teachers would be considered satisfactory. Small numbers are expected as Graphics Technology is not a subject taught by all NSW High Schools or all Technology Education faculties. Delivery of this course is based on teacher expertise and interest only.

\subsection{Selection of the Key Informants}

For the face-to-face semi-structured interviews, due to the constraints of distance, local (Coffs Harbour region in NSW) professionals will be chosen for this part of the study as the key informants. It is anticipated that due to the expectations of their roles in dealing with human settlement issues and the environment, and the qualifications required to gain employment in these roles, that validity of the data will not be compromised as a result of sourcing them locally.

These key informants will be found via a search of local business directories and the internet. The intended number of participants in the face-to-face semi-structured interviews will be confined to three. These could be either male or female participants (gender is not important for the purposes of this study). I have chosen three participants because I am after opinions from key informants from these three areas who deal with the nexus between the environment and humans settlements regularly:

Occupational areas that the professional participants are drawn from:

1) Local government Town planning Department. This person would be involved in the assessment and approval of development in specified areas of the council's region. Assessment on a daily basis requires the evaluation of planned developments in light of an environmental assessment of the area.

2) A local Architect who regularly designs structures in this area; their knowledge of design and designing to satisfy council requirements and the intended local is desired for this study. Architects design human spaces that function within designated environments.

3) An ecological consultant. This person's role is to be more of an advisor and an advocate for the environment. This person would be able to offer objective information on environmental impact of a development and their role would be to offer advice on impact mitigation.

\subsection{Online Survey}

The following online questions will be asked of the Teacher Participants:

1) How long have you been teaching the Architectural Drawing Module of the Graphics Technology syllabus, and why have you chosen it offer it to your students?

2) The Architectural Drawing Option Module of the Graphics Technology syllabus requires students to design ecologically friendly Architectural spaces. Please list any identifiable criteria that you would consider an Architectural space to have, to be considered "ecologically friendly".

3) Have you had any formal training or Professional Learning in designing ecologically friendly Architectural spaces? If not, then how do you inform yourself regarding eco-design?

4) If you had an opportunity to develop your understanding in this area, what action would you take? And what questions would you be seeking to answer?

\subsection{Interview Questions}

1) In your opinion, what could be classed as an Architectural space?

2) Graphics Technology high school teachers are required to teach their students about environmental issues relating to Architectural design. Based on your own knowledge in this area, what would you see as the important environmental issues relating to Architectural design that they should be teaching about?

3) If we were to compare two spaces: One being "ecologically friendly" and one not being "ecologically friendly". What features of the space would make it "ecologically friendly".

\section{Results}

\subsection{Online Surveys}

There were 11 teachers who responded to the survey. This was a small number, but this was expected as indicated 
earlier in this paper. All of the respondents claim not to have had formal training or professional development in designing ecologically friendly architectural spaces, although two mentioned past studies in design- this may or may not have explicitly taught eco-friendly concepts. Several expressed a strong interest in getting training or being passionate about learning, and most talked about achieving this by doing their own research. This was largely through their own reading, and by discussions with colleagues. Reading sources range widely from professional articles to "some old textbooks we have". Most appear to be read widely ("extensive research and reading over the years") and do this out of personal interests ("reading and research in own time"). Two referred explicitly to the Internet as a source of information ("resources on the net"; "internet forums"), while two others commented on their use of television (for example, "watching T.V. show (grand designs)"). The second main way respondents developed their expertise is through discussions, with both teaching and industry colleagues; one mentioned "family and friends in the building industry". Two commented on responding to questions and needs: "have had people ask about more Eco-friendly", and "teaching, exploring how to do this with design and technology in stage 6," a senior school subject.

The respondents provides a range of options of what they would do, had they the opportunity to develop their understanding in the area. Despite the enthusiasm noted above, the responses were more ambivalent. Some looked to professional learning, with one noting that he would "engage in any professional development that was costed appropriately for the school to afford". Another teacher stated that they would "love to go to a workshop and get trained in how better to teach this unit". Others, on the other hand, saw their own self-directed professional learning as important. "I will continue to extend myself through reading", commented one, while another noted, "research, web, use books, seek library help at work to look up resources etc., update my eco information."

Others responded to this question differently, describing the content they may need to learn rather than the process of professional learning, "what makes the best solution and how do you evaluate it"; "not necessarily questions but just looking for a more rounded and up to date knowledge"; or "building and architecture specific". The remaining teachers were less sure, as two did not comment, and one suggested he needed more time to research.

To deconstruct the result from the individual Technology Teacher surveys:

Based on the first part of Question 1, "how long have you been teaching the Architectural Drawing module of the Graphics Technology syllabus?” The results indicate that of the nine years that the syllabus has been taught, 3 teachers (27\%) had been teaching to the syllabus since its introduction in 2003. Following this, 6 teachers (55\%) had been teaching it for 4 years or more, and the remaining " 2 teachers $(18 \%)$ have only been teaching this Option Module for 2 years or less. The purpose of this question was to determine how experienced these teachers are in the delivery of this Option Module to their students.

The second question was designed to determine teachers' knowledge and understanding of what an ecologically friendly Architectural space is. The participants' responses are summarised in Figure 1. The question asked teachers to list any identifiable criteria that they would consider an ecologically friendly Architectural space to have. From the data collected, there were two criteria that were identified by all participants (100\%), these were to reduce energy consumption for lighting, and to reduce energy consumption for heating and cooling. Following this, seven of the participants (64\%) identified a reduction in materials from either recycling or reduction in footprint (size) of the Architectural space. Other criteria suggested that these spaces may improve the surrounding external environment (50\%). There were three other identified criteria, each from teachers (40\%). These criteria were spaces that improve the immediate micro environment. Spaces that select materials based on a minimal embodied energy rating, and finally a space that aims to reduce water consumption.

To assist in the analysis between teacher understanding and Key Informants understanding later in this paper, the criteria identified by the teachers as "eco-friendly" will be labelled from "a" through to "g".

This labelling is found in Table 1.

Considering that all of the teacher participants had to teach to and assess the outcome, the third question was seeking to determine how teachers were educated in the development of their own knowledge of ecologically friendly Architectural spaces. The question asks teachers, "Have you had any formal training or professional learning in designing ecologically friendly Architectural spaces?” The results indicate that two teachers (18\%) had received formal instruction from university study, whilst an overwhelming majority of nine teachers (82\%) and not received any formal instruction.

Though not required as part of the initial survey, the teachers did offer additional information that was important in determining how teachers are educating themselves informally. This additional data was collected, 


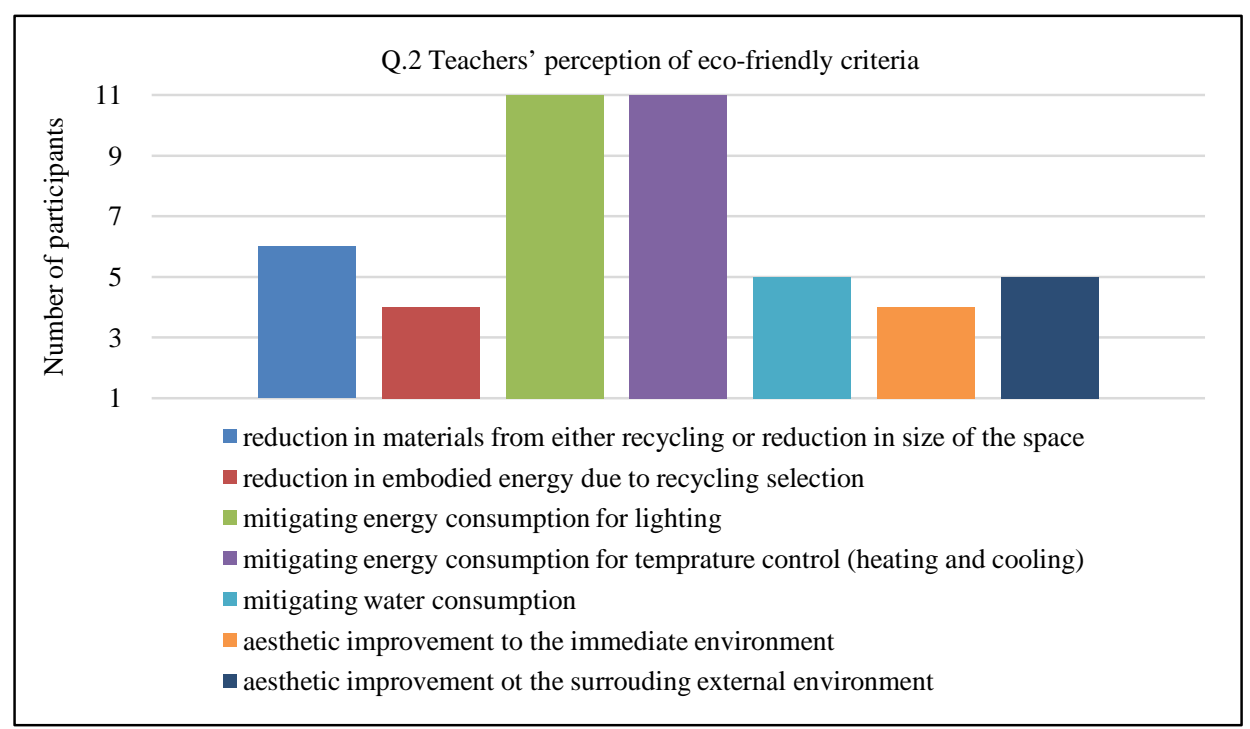

Figure 1. Teacher participants’ perception of eco-friendly criteria.

Table 1. The labelling of criteria collected from teacher participants.

\begin{tabular}{cc}
\hline Q.2 Teachers perception of eco-friendly criteria & Label \\
\hline Reduction in the used of materials from either recycling or reduction in the size of the space & a \\
Reduction in the embodied energy of materials due to the selection of recycled items & b \\
Mitigating energy consumption for temperature control (heating and cooling) & d \\
Mesthetic improvement to the immediate environment & e \\
Aesthetic improvement to the surrounding environment & $\mathrm{f}$ \\
\hline
\end{tabular}

analysed and graphed in Figure 2. From the survey data, eight teachers (73\%) preferred to develop their understanding using internet based articles. Some teachers gave more than one preferred method with $27 \%$ of the teachers gaining information from the television, and dialogue amongst colleagues and professionals.

This followed onto the final question where the teacher participants were asked, "If you had an opportunity to develop your understanding in this area, who would you consult? And what questions would you ask of this person/ organisation? The intention of the question was to determine what the preferred method of professional develop the teachers would like to receive, noting that it may differ from the method that they have used to acquire information to date. The results from this question are represented in Figure 3. The survey data indicated that four teachers (36\%) preferred self-directed or autonomous professional learning opportunities. Following this three teachers (27\%) of teachers were not sure what professionals they would consult or ask. From an education perspective, two teachers (18\%) expressed interest in learning from experts in terms of how to teach the outcomes effectively. One teacher (9\%) wanted to know more about building, however they didn't specify how they would prefer to obtain this information. Finally, one teacher (9\%) did not express any interest in professional learning as they were happy with their level of understanding.

\subsection{Professional Interviews}

To assess the accuracy of the teacher participants understanding of what eco-friendly Architectural spaces are, three key informants were interviewed and asked to answer four semi-structured questions. The intention was to 


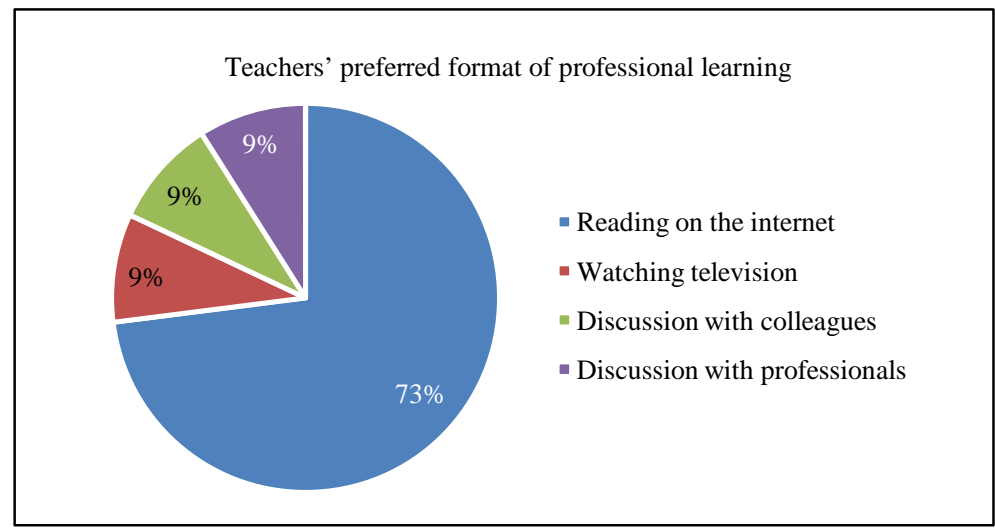

Figure 2. Technology educators preferred method of professional learning.

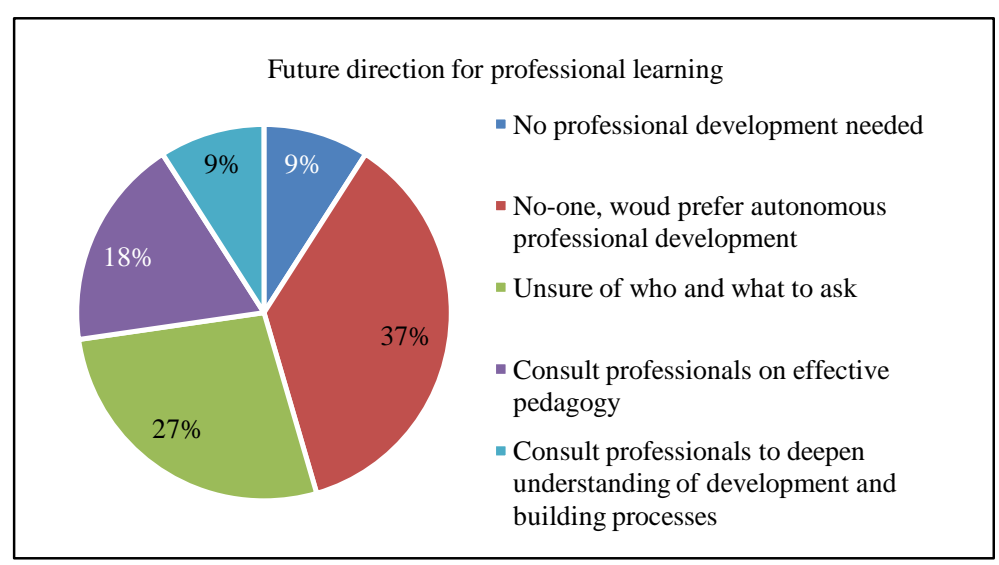

Figure 3. The direction teacher participants would take to develop an understanding of what eco-friendly architectural spaces are.

provide a depth of understanding, due to the richness of an extended answer. As there are only three key informants, for the purposes of this paper I will discuss the results individually.

The first question asked the key informants, "In your opinion, what could be classed as an Architectural space? The Town Planner described an Architectural space as any space adjacent to or containing a man-made structure or building. This answer was informative as it provided an insight into the planning, design and execution of spaces next to a man-made structure.

The Ecologist described an Architectural space as the building, and the surrounding area to the building. This area may be impacted on by the building, for example the building has an impact on the immediate landscaping, or a visual impact. The design of the building may impact on the surrounding environment in a way that it may appear to be "out of place".

During the interview, the Architect wanted to first dedicate some thought to determine what non-Architectural spaces were to assist in the definition of Architectural spaces. He deliberated on the answer, then stated that, an Architectural space is "a space that has been interfered with by humans". It is a space that has been considered, then constructed or modified. An Architectural space is a physical 3D space that people can move in, around and out of.

The key informants were informed that Graphics Technology high school teachers are required to teach their students about environmental issues relating to Architectural design. They were asked; based on your own knowledge in this area, what would you see as the important environmental issues relating to Architectural design that they should be teaching about? The relevance of this question was to provide an opportunity and insight from professionals in the field.

The Town Planner did not discuss the structure of the space itself, but chose to stick with the assessment of 
the land and the preparation of it for development. This is consistent with the role of a town planner. He provided answers as a series of broad points. These points could act (and may already act) as a checklist for designers to consider. These were: An analysis of the site to determine its dimensions, its topography and existing vegetation of the surrounding area. The designer then needs to determine externalities like the aspect in terms of sun and wind before an assessment to determine any site modification for drainage or other required services such as water and power.

The Ecologist's answers to the second question was also consistent with their role in providing advice to mitigate environmental issues, however their answer provided considerations that were additional to the town planners. Regarding the construction of the structure, they described the importance of selecting building materials with a lower embodied energy. They also described the impact on the environment as a result of using the space, such as the reduction of waste and its safe disposal. One specific mention was the introduction of foreign species the area where the space is located. Examples such as the planting of plants, and introduction of fish that are foreign to the area may result in the introduction of pests and weeds. They stated that designers should consider the introduction of native species to Architectural spaces.

The Architect described two separate types of environmental issues; egocentric and energy centric issues. Egocentric issues focus on the "micro" environment, being the issues that exist between the user of the space and the environment, incorporating an awareness of how the space affects the user. The Architect asks us to consider the needs of the user, for example, whether the space is designed for a primary school student or an older person as their requirements are different. The architect elaborated further by stating that due to the egocentric nature of users experiences within spaces, there are also environmental issues associated with a lack of connectedness between the outside environment and the user within a space. This lack of connectedness can lead to environmental issues where spaces are designed that ignore the surrounding area (an extreme example of this is the snow ski resort built in the Dubai desert-S. Spector et al. 2012).

Regarding energy centric environmental issues, the Architect described that a life cycle analysis (LCA) of the space would identify environmental issues, such as the embodied energy required to provide the materials for the space. In using the space it would identify what energy is required to make the space more comfortable in terms of heating and cooling? At the end of the construction and useable life of the space, are there any materials left over in the construction of the space and what energy is required to remove or disassemble the space?

The third and final question for the interview asked the key informants, if they were to compare two spaces: One being "ecologically friendly” and one not being "ecologically friendly”, what features of the space would make it "ecologically friendly”? The purpose of this question was to enable a comparison between the teachers' answers regarding eco-friendly criteria and the answers of the key informants. The purpose of this was to determine the accuracy of the teachers' professional development.

The criteria described by the Town Planner was quite broad as he suggested the incorporation of a Life Cycle Assessment (LCA).This would quite comprehensively look the environmental impacts of the space (and its components) in its construction, its use and disposal. To map this against the criteria discussed by the Teachers in this study, architectural spaces that would "rate” better in their LCA would align with all the criteria from "a" to "e". Separate to a LCA, the second part of the Town Planner's discussion described the physical features of the space that may reduce its environmental impact. Features such as eaves, and the orientation of the space on the site, would reduce the energy requirements by passively heating or lighting the space. As a result, this assessment would align with criteria “c” and “d”. Finally the Town Planner used the term "appropriateness” when assessing the design of the space for its intended site. This term can incorporate a the range of criteria, but in this context, aside from performance criteria, the term appropriateness will align with the aesthetic criteria labelled as $\mathrm{f}$ and $\mathrm{g}$ in Table 2.

The Ecologist discussed the assessment of a space based on the selection of the building materials and components that make up the space with an overall theme of "less" is better. These spaces would be assessed by their attempts to not only minimise the waste, but minimise the embodied energy that is found within each material. The space would also be assessed according to the waste to be disposed of. Less waste is preferred as it would add to the landfill. This theme of assessing the space based on the reduction of environmental impact is consistent with an LCA that was discussed by the Town Planner. The comments built on a theme of environmental impact in the space's construction and disposal but no use. As a result energy expended in using the space was not discussed and therefore would not align with the criteria from "c" to "e". In addition, the Ecologist discussed the potential assessment of the plants used in these Architectural spaces. The aim of this is to 
Table 2. The following comparative task used the criteria labelled as "a" to "g" developed by the Teacher Participants from Table 1. This was mapped against the criteria described by the Key Informants below.

\begin{tabular}{ccccccccc}
\hline Key Informants & \multicolumn{7}{l}{ Similarity between teachers perceptions and key informants } \\
\hline Criteria labelled from Figure 1 & a & b & c & d & e & f & g \\
\hline Town Planner & X & X & X & X & X & X & X \\
Ecologist & X & X & & & X & X \\
Architect & X & X & X & X & X & 0 & 0 \\
\hline
\end{tabular}

$\mathrm{X}=$ direct link between Teacher Participants and Key Informants answers; 0 = related link between Teacher Participants and Key Informants answers.

promote the use of native over foreign (potential weed) plant species. For the purposes of this study, the incorporation of plants into a space would be to improve the aesthetic appeal of the micro environment this would align with criteria " $\mathrm{f}$ " and "g".

The Architect's comments reflected on the features or components of the space that would impact on the overall performance of the space, but unlike the other Key Informants, his focus was also on the assessment of the user experience. Unlike the comparison of embodied energy found within different materials, the Architect's suggestion in determining whether the space was friendly or not was the determination of its satisfaction or contentment in meeting the needs of the user. In this way he discusses the concept of the "micro" environment, not from an aesthetic perspective, but a performance perspective. In an attempt to align the user's satisfaction of the space a related link is the satisfaction in the way the user likes the space. It could be argued that the user would also like the look, appearance or aesthetic appeal of the space. Therefore this is not a direct link, but a related link to criteria " $f$ " and "g". He also discussed the efficiency of materials use, and how less is more efficient. Like an LCA, this is consistent with an assessment of the "inputs" of a space, and would appropriately align with criteria "a" and "b".

Aside from the user's experience, the Architect also mentioned the physical characteristics of the design, incorporating site and passive solar opportunities. These would align with criteria "c" and "d" in reducing the energy inputs required to heat, cool and light the space. His final theme discussed the role of an architect in designing to comply with regulatory authorities as they attempt to realise safer and more environmentally friendly spaces through good policy. The Building Sustainability Index (BASIX) is "implemented under the Environmental Planning and Assessment Act. Is an example of good policy to that applies to all residential dwelling types and is part of the development application process in NSW" (Department of Planning and Environment, n.d.). The BASIX assessment of a planned space aims to assist in reducing water and energy consumption through considered design. The assessment of spaces using a BASIX approach aligns directly with criteria "a" to "e" in Table 2.

\section{Discussion}

This article provided an example of how curriculum can change. The change discussed has been the result of political will and action in an optimist pursuit that future Australians will "have the awareness, knowledge, skills, values and motivation to live sustainably" (DEWHA, 2009: p. 17), and therefore a cultural construct developed at a specific time. The impetus for there to be cooperation between human society, economic development and the environment, has been discussed and an example has been provided of how Australian government strategies been developed to "ensure sustainability is formally addressed in curricula" (DEWHA, 2009: p. 24).

In the realisation of political will as a social construct and its influence in education, it is important to acknowledge the work of Grundy (1998) and Schwab (1969) in labelling curriculum as a dynamic, ever changing process. As teachers change their pedagogy to suit different students and environments, the subject matter that they have expertise in also changes as the curriculum evolves. As a result of what Grundy (1998) has coined a "pedagogical" view of curriculum, teachers need to be lifelong learners with an ability to quickly adapt to change in the event of curriculum change as well as the other identified elements of the teacher, the students and the milieu (Grundy, 1998). In the context of the case study of technology educators teaching the NSW Graphics Technology syllabus content, the results of the survey support the concept of curriculum change. In the case study, a significant percentage of $82 \%$ of the teachers indicated that they had not been trained in this content 
meaning that they had to rely own their own professional learning following their initial teacher education.

A courteous glance at what is happening in higher education settings might suggest that the Talloires Declaration will result in teachers receiving the desired training in environmental education that will lead to improved student learning outcomes (Zak \& Munson, 2008), however after further analysis (Christie et al., 2013) much of the implementation of sustainability into universities has been limited to operational matters rather than curriculum. In what appears to be the autonomous approach to assist pre-service teachers in becoming environmentally literate (Christie et al., 2013), we see that as environmental education is embedded in curriculum more holistically (Tilbury, 1995) the wider the gap will be between all teachers and those who are environmentally literate themselves.

Given the inadequate coverage of environmental education in initial teacher education programs, and to continue with the serendipitous approach of pre-service teachers being taught by interested academics, what is required of pre-service teachers is the ability in learning how-to learn (Starkey, 2009) and how-to adapt to quickly master new knowledge (Darling-Hammond et al., 2005). This “adaptive expertise” (Hatano \& Inagaki, 1984) is required as pre-service teachers need to understand that initial teacher education is foundational, and to be an expert teacher, you must be prepared to "transform old routines and traditional beliefs" (Darling-Hammond et al., 2005: p. 365) to implement change otherwise learning new knowledge is only half the job. "Some teachers will understand and embrace a major change in practice, while others many of whom are highly experienced and considered "expert" in important ways will oppose the change for a variety of reasons making it important for professional learning to allow discussion of the rationale and principles as well as the "how to" in effecting change" (Starkey et al., 2009).

As teacher professional learning is increasing aligned with teacher registration requirements (AITSL, 2011) a challenge for individual teachers as well as the "system" is to ensure professional learning is appropriate and informed, as well as flexible. There are different ways teachers can undertake professional learning and opportunities for professional learning may not always be available (Bayer, 2014). The tension that exists between becoming an adaptive expert engaging in life-long learning opportunities and the unfettered independence of self-directed methods where these autonomous methods could impact on the quality of environmental education outcomes (Robottom, 1983). The case study example indicated that $73 \%$ of the teacher participants preferred autonomous professional learning, but is the information they are obtaining accurate? And, if not, then ignorance may be bliss (Effeney \& Davis, 2013). An example of this was evident in the research into the knowledge of sustainability in primary pre-service teachers, where pre-service teachers were not "constrained by their lack of knowledge" (p. 41) and quote Kruger and Dunning (1999) by suggesting that they may have an "inflated perception of their own abilities” (Effeney \& Davis, 2013: p. 41).

Learning Area diversity adds to the challenge of accessing formal professional learning opportunities. In the case study example of technology educators who were teaching Graphics Technology, they are often required to choose four "Option Modules" from fourteen diverse (and often internationally standardised) graphics Option Modules (NSW Board of Studies, 2003). As a result, technology education teacher programs cannot cover this diversity and must rely on graduate teachers to adopt a mind-set of lifelong learning for adaptive expertise. Given this situation, the question that has arisen from this article and proposed a direction for future research is, what would a learning framework look like that is specific to autonomous professional learning opportunities for effective professional learning? Given the willingness, and the clarity and depth of information that the Key Informants provided, surely part of this framework could involve the linking with experts to validate newly acquired teacher knowledge (Fraser, 2010).

To determine whether the autonomous professional learning experiences can be appropriate, the case study aimed to compare the understanding of what teachers perceived to be eco-friendly criteria in the context of designing architectural spaces and the understanding of key informants who are qualified experts working in the areas of architectural design, town planning and ecological consultancy. As a result of the intrinsic motivation behind teachers seeking to "know" and "understand" their subject matter they are teaching, the results suggest that self-directed or autonomous professional learning does lead to the development of a basic understanding of new information. By analysing the differences in understanding between the teacher participants and the key informants it is not surprising that the key informants possessed a greater understanding of eco-friendly criteria, but this was specific to the roles that their occupation requires as all of them discussed the environment that the architectural space was located in, meaning that the relationship between the space and the surrounding environment is important. See Figure 4 as a representation of this. To incorporate the value that different perspectives 


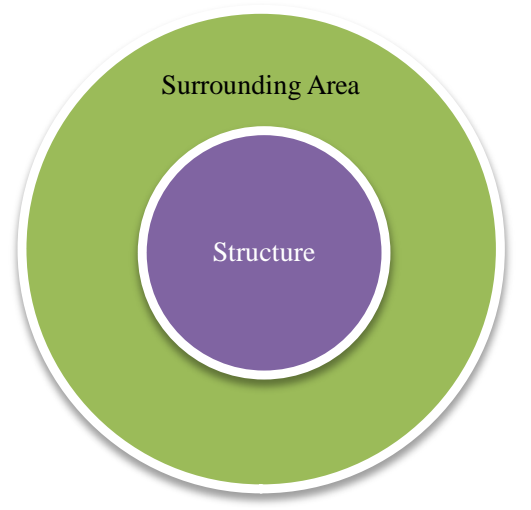

Figure 4. Key informants interpretation of an architectural space and how it sits within the surrounding environment.

provide, we may address the tensions of sustainable development where "the examination of socio-political issues helps develop a more holistic (connected) understanding of human dependence on the environment for making informed decisions on sustainable patterns of living” (Forest Learning, n.d.: p. 1).

Following this study, it could be suggested that to develop a holistic understanding of subject matter that is necessary according to Gough, Robottom and Tilbury, information not covered in formal teacher training, could be developed when autonomous professional learning experiences incorporate opportunities for teachers to liaise with relevant key informants, recognising their perspectives, and developing their expertise of the new curriculum. As stated by the Victorian Curriculum and Assessment Authority in 2008 "Partnerships can create opportunities for the development of shared understandings of learning” (p. 6).

\section{Limitations of the Study}

The study examined the inclusion of one outcome to the New South Wales Graphics Technology syllabus document, and participant's understanding of that outcome post initial teacher education. The analysis and results of the survey data are not intended to be representative of a participants overall knowledge of graphics technology, nor does it question the quality of initial teacher education programs in New South Wales. This result upholds the concept of curriculum evolution and the need to teachers to engage in continuous professional learning as new subject matter may be included, that originally been considered irrelevant to technology education initial teacher education programs.

\section{Conclusion}

The results of the survey data indicate that the majority of teacher participants have not received any formal training in what an eco-friendly architectural space is, even though they are currently teaching it, and to develop their understanding, they have had to resort to engaging in informal professional learning. In determining the accuracy of their understanding of what an eco-friendly architectural space is, a comparative analysis of criteria identified by the teacher participants was compared against the criteria identified by key informants who are working in relevant professions. The results indicated that the understanding the teachers gained was appropriate, if not relatively superficial, but adequate for the purposes of the Graphics Technology subject.

Regarding the methods that these technology education teachers preferred to use to learn new subject matter, the survey data indicated that the majority of the teacher participants preferred to engage in professional learning autonomously. The survey also indicated that if given the choice, the teacher participants preferred to engage in professional learning using the internet as their source of information.

\section{References}

Australian Curriculum, Assessment and Reporting Authority (ACARA) (2012). The Shape of the Australian Curriculum Version 3. Sydney: ACARA.

Australian Institute for Teaching and School Leadership (AITSL) (2013). The Essential Guide to Professional Learning: 
Evaluation. Melbourne: AITSL.

Australian Institute for Teaching and School Leadership (AITSL) (2011). National Professional Standards for Teachers. Melbourne: AITSL.

http://www.aitsl.edu.au/docs/default-source/apst-resources/australian_professional_standard_for_teachers_final.pdf

Ball, D. L., \& Cohen, D. K. (1999). Developing Practice, Developing Practitioners: Toward a Practice-Based Theory of Professional Education. In G. Sykes, \& L. Darling-Hammond (Eds.), Teaching as the Learning Profession: Handbook of Policy and Practice (pp. 3-32). San Francisco, CA: Jossey Bass.

Barron, D., Jackson, S., \& Anderson, L. (2005) Ignorance, Environmental Education Research and Design Education. Australian Journal of Environmental Education, 21, 39-46.

Bayer, A. (2014) The Components of Effective Professional Development Activities in Terms of Teachers’ Perspective. International Online Journal of Educational Sciences, 6, 319-327. http://dx.doi.org/10.15345/iojes.2014.02.006

Bohle Carbonell, K., Stameijer, R., Konings, K., Segers, M., \& van Merrienboer, J. (2014) How Experts Deal with Novel Situations: A Review of Adaptive Expertise. Educational Research Review, 12, 14-29. http://dx.doi.org/10.1016/j.edurev.2014.03.001

Bransford, J. D., Brown, A. L., \& Cocking, R. R. (2000) How People Learn: Brain, Mind Experience, and School. Washington, DC: National Academy Press.

Bransford, J. D., Vye, N., Bateman, H., Brophy, S., \& Roselli, R. (2004). Vanderbilt’s Amigo3 Project: Knowledge of How People Learn Enters Cyberspace. In T. Duffy, \& J. Kirkley (Eds.), Learner-Centered Theory and Practice in Distance Education. Mahwah, NJ: Erlbaum.

Bransford, J., Vye, N., Stevens, R., Kuhl, P., Schwartz, D., Bell, P., Roschelle, J. et al. (2005). Learning Theories and Education: Toward a Decade of Synergy. Handbook of Educational Psychology (2nd Edition), 95 p.

Brundtland, G. H. (1987). Our Common Future. Brussels: World Commission on Environment and Development. http://www.un-documents.net/ocf-ov.htm\#1.2

Christie, B. A., Miller, K. K., Cooke, R., \& White, J. G. (2013). Environmental Sustainability in Higher Education: How Do Academics Teach? Environmental Education Research, 19, 385-414. http://dx.doi.org/10.1080/13504622.2012.698598

Collins, R. (2014). Skills for the 21st Century: Teaching Higher-Order Thinking. Curriculum \& Leadership Journal, 12, No. 14.

Cornish, J. (2005) Extending the Vision: Australian Government Engagement with the UN Decade of Education for Sustainable Development 2005-2014. http://www.environment.gov.au/education/publications/vaee-05/index.html

Crawford, V., \& Brophy, S. P. (2006). Adaptive Expertise: Theory, Methods, Findings, and Emerging Issues. Symposium Report.

Darling-Hammond, L., Bransford, J., LePage, P., Hammerness, K., \& Duffy, H. (2005). Preparing Teachers for a Changing World: What Teachers Should Learn and Be Able to Do. San Francisco, CA: Jossey-Bass.

De Arment. S. T., Reed, E., \& Wetzel, A. P. (2013). Promoting Adaptive Expertise: A Conceptual Framework for Special Educator Preparation. Teacher Education and Special Education: The Journal of the Teacher Education Division of the Council for Exceptional Children, 38, 207-220.

Department of Education and Communities (2013). Great Teaching, Inspired Learning: A Blueprint for Action. http://www.schools.nsw.edu.au/media/downloads/news/greatteaching/gtil_blueprint.pdf

Department of Education and Communities (2014). Media Release: Teachers Keep Learning to Improve Students. http://www.dec.nsw.gov.au/about-us/news-at-det/media-releases1/teachers-keep-learning-to-improve-students

Department of Planning and Environment, NSW (n.d.). BASIX Design Principles. https://www.basix.nsw.gov.au/basixcms/basix-help-notes/energy/design-principles-energy.html

Department of the Environment, Water, Heritage and the Arts (DEWHA) (2009). Living Substantially: The Australian Government's National Action Plan for Education for Sustainability. Canberra. https://www.environment.gov.au/system/files/resources/13887ab8-7e03-4b3e-82bb-139b2205a0af/files/national-action-pl an.pdf

Effeney, G., \& Davis, J. (2013). Education for Sustainability: A Case Study of Pre-Service Primary Teachers' Knowledge and Efficacy. Australian Journal of Teacher Education, 38, 31-46. http://ro.ecu.edu.au/ajte/vol38/iss5/3 http://dx.doi.org/10.14221/ajte.2013v38n5.4

Forest Learning (n.d). Socio-Political Issues in Forestry. http://forestlearning.edu.au/find-a-resource/article/13/socio-political-issues-in-forestry.html

Fraser, N. (2010). Eco-Schools Scotland: Lessons Learned from First-Hand Experience. School Science Review, 92, 67-72. 
Geohive (2014). Global Statistics/Population Statistics. http://www.geohive.com/

Gough, A. (2002). Mutualism: A Different Agenda for Environment and Science Education. International Journal of Science Education, 24, 1201-1215. http://dx.doi.org/10.1080/09500690210136611

Grundy, S. (1998). The Curriculum and Teaching. In E. Hatton (Ed.), Understanding Teaching (2nd ed.). Sydney: Hardcourt Brace.

Hargreaves, A., \& Shirley, D. (2012). The Global Fourth Way: The Quest for Educational Excellence. Thousand Oaks, CA: Corwin.

Hatano, G., \& Inagaki, K. (1986). Two Courses of Expertise. In H. Stevenson, H. Azuma, \& K. Hakuta (Eds.), Child Development and Education in Japan (pp. 262-272). New York: Freeman.

http://eprints.lib.hokudai.ac.jp/dspace/bitstream/2115/25206/1/6 P27-36.pdf

Hirsh, S. (2001). We're Growing and Changing. Journal of Staff Development, 22, 255-258.

Kennedy, M. M. (1999). The Role of Preservice Teacher Education. In L. Darling-Hammond, \& G. Sykes (Eds.), Teaching as the Learning Profession: Handbook of Teaching and Policy (pp. 54-86). San Francisco, CA: Jossey Bass.

Kimball, D. R., \& Holyoak, K. J. (2000). Transfer and Expertise. In E. Tulving, \& F. I. M. Craik (Eds.), The Oxford Handbook of Memory (pp. 109-122). New York: Oxford University Press.

Lin, X., Schwartz, D. L., \& Hatano, G. (2005)Towards Teachers’ Adaptive Metacognition. Educational Psychologist, 40, 245-255. http://dx.doi.org/10.1207/s15326985ep4004_6

Ministerial Council on Education, Employment, Training and Youth Affairs (MCEETYA) (1998). Australia's Common and Agreed Goals for Schooling in the Twenty First Century: A Review of the 1989 Common and Agreed Goals for Schooling in Australia (The Hobart Declaration). http://www.curriculum.edu.au/verve/_resources/natgoals_file.pdf

Ministerial Council on Education, Employment, Training and Youth Affairs (MCEETYA) (2008). Melbourne Declaration on Educational Goals for Young Australians.

http://www.curriculum.edu.au/verve/_resources/National_Declaration_on_the_Educational_Goals_for_Young_Australian s.pdf

Mulà, I., \& Tilbury, D. (2011). National Journeys towards Education for Sustainable Development, 2011: Reviewing National Experiences from Chile, Indonesia, Kenya, the Netherlands, Oman.

http://unesdoc.unesco.org/images/0019/001921/192183e.pdf

Mylopoulos, M., \& Regehr, G. (2009). How Student Models of Expertise and Innovation Impact the Development of Adaptive Expertise in Medicine. Medical Education, 43, 127-132. http://dx.doi.org/10.1111/j.1365-2923.2008.03254.x

NSW Board of Studies (2003). Syllabus in Graphics Technology, Years 7-10. Sydney: NSW Board of Studies.

Organisation for Economic Co-operation and Development (OECD) (2009) Creating Effective Teaching and Learning Environments: First Results from TALIS. Paris: OECD.

Palardy, G. J., \& Rumberger, R. W. (2008). Teacher Effectiveness in First Grade: The Importance of Background Qualifications, Attitudes, Instructional Practices for Student Learning. Educational Evaluation and Policy Analysis, 30, 111-140. http://dx.doi.org/10.3102/0162373708317680

Robottom, I. (1983). Science: A Limited Vehicle for Environmental Education. Australian Science Teachers Journal, 29, 27-31.

Schwab, J. (1969). College Curricula and Student Protest. Chicago, IL: University of Chicago Press.

Schwartz, D. L., Bransford, J. D., \& Sears, D. (in press). Efficiency and Innovation in Transfer. In J. Mestre (Ed.), Transfer of Learning: Research and Perspectives. Greenwich, CT: Information Age Publishing.

Starkey, L., Yates, A., Meyer, L. H., Hall, C., Taylor, M., Stevens, S., \& Toia, R. (2009). Professional Development Design: Embedding Educational Reform in New Zealand. Teaching and Teacher Education, 25, 181-189. http://dx.doi.org/10.1016/j.tate.2008.08.007

Tilbury, D. (1995). Environmental Education for Sustainability: Defining the New Focus of Environmental Education in the 1990s. Environmental Education Research, 1, 195-213. http://dx.doi.org/10.1080/1350462950010206

Tuncer, G., Tekkaya, C., Sungur, S., Cakiroglu, J. U., Ertepinar, H., \& Haplowitz, M. (2009) Assessing Pre-Service Teachers’ Environmental Literacy in Turkey as a Mean to Develop Teacher Education Programs. International Journal of Educational Development, 29, 426-436. http://dx.doi.org/10.1016/j.jjedudev.2008.10.003

UNCED (1993). Agenda 21: Programme of Action for Sustainable Development. The Final Text of Agreements Negotiated by Governments at the United Nations Conference on Environment and Development (UNCED), Rio de Janeiro, 3-14 June 1992.

UNDESA (2011). World Population Prospects, the 2010 Revision. Volume !: Comprehensive tables. ST/ESA/SER.A/313. http://esa.un.org/wpp/Excel-Data/population.htm 
UNESCO (2007). The UN Decade of Education for Sustainable Development (DESD 2005-2014). The First Two Years. http://unesdoc.unesco.org/images/0015/001540/154093e.pdf

UNESCO (2011). Education for Sustainable Development: An Expert Review of Processes and Learning. http://unesdoc.unesco.org/images/0019/001914/191442e.pdf

Victorian Curriculum and Assessment Authority (2008). Analysis of Curriculum/Learning Frameworks for the Early Years (Birth to Age 8). Melbourne: Victorian Curriculum and Assessment Authority.

http://www.vcaa.vic.edu.au/documents/earlyyears/analysiscurriclearnfwlitreview.pdf

Yin, R. K. (2009). Case Study Research: Design and Methods. Thousand Oaks, CA: Sage.

Zak, K., \& Munson, B. (2008). An Exploratory Study of Elementary Preservice Teachers' Understanding of Ecology Using Concept Maps. Journal of Environmental Education, 39, 32-46. http://dx.doi.org/10.3200/JOEE.39.3.32-46 